\title{
Speaking for a Child: The Role of Independent Counsel for Minors
}

Minors have an ambiguous status in American society. The law protects them from even their own mistakes, ${ }^{1}$ and yet they are unique individuals who will eventually possess the autonomy of adult citizens. Thus, an enduring tension exists between the desire to safeguard the interests and welfare of children and the responsibility to respect the rights and dignity of developing human beings. In the past, the American legal system has tended towards paternalism, but in the last few decades the balance has begun to shift.

One result of the increasing recognition of children's rights has been the emergence of independent legal representation for minors. ${ }^{2}$ Unfortunately, such representation has been unpredictable and imconsistent. Practitioners and scholars disagree widely on the proper role of the child's attorney, and current professional responsibility guidelines do not resolve the dilemma.

This Comment proposes extending professional responsibility tenets to provide guidance to attorneys who represent minors. Founded on the premise that the attorney's duty is to represent the minor's views, the proposal thereby upholds the minor's rights and dignity as an imdividual. Under this premise, the attorney lacks the authority to decide what is best for the minor. Rather, it is the role of the judge to determine the best interests of the minor and ultinately to protect the minor's welfare even if that requires disregarding the minor's personal wishes.

Part I of this Comment describes the traditional legal structure im which parents and the state function as substitute decisioumakers for the ininor. Part II discusses the emergence of independent legal representa-

1. [T] he [United States Supremel Court has held that the States validly may limit the freedom of children to choose for themselves in the making of important, affirmative choices with potentially serious consequences. These rulings have been grounded in the recognition that, during the formative years .... minors often lack the experience, perspective, and judgment to recognize and avoid choices that could be detrimental to them.

Bellotti v. Baird, 443 U.S. 622, 635 (1979) (plurality opinion); see also Schall v. Martin, 467 U.S. 253, 264-66 (1984) (discussing the state's interest "in protecting the juvenile from his own folly") (quoting People ex rel. Wayburn v. Schiff, 39 N.Y.2d 682, 688-89, 350 N.E.2d 906, 909 (1976)).

2. The debate over whether and under what circunstances independent counsel should be appointed is beyond the scope of this Comment. For a comprehensive discussion of this issue, see Guggenheim, The Right to be Represented But Not Heard: Reflections on Legal Representation for Children, 59 N.Y.U. L. REv. 76 (1984) (discussing the views of various commentators). Rather, this Comment accepts the existence of independent counsel for minors as a given. See, e.g., In re Gault, 387 U.S. 1 (1967) (upholding a minor's right to counsel in deliquency proceedings). 
tion of minors and the conflict concerning the appropriate role of the child's attorney. Part III examines Rule 1.14 of the American Bar Association Model Rules of Professional Responsibility, which directs that an attorney should treat a minor like a regular client to the extent "reasonably possible,"3 and proposes extending Rule 1.14 in two regards. First, this Comment suggests a inaturity inquiry to determine if the minor is competent to direct his attorney. Second, it proposes that if the minor is not competent to direct the case, the attorney should act under the doctrine of substituted judgment in order to make decisions as a surrogate. In this way the attorney should attempt to reach the decision the minor, if sufficiently mature and competent, would make. This proposal thus atteinpts to confine the attorney to the traditional role as her client's agent. $^{4}$

\section{Traditional Legal Treatment of Minors}

Minors by definition ${ }^{5}$ are legally disabled by their age and thus are disqualified from making fundamental decisions about their own lives. ${ }^{6}$ Unless emancipated, ${ }^{7}$ or given specific authority by state statutes, ${ }^{8}$ minors cannot validly contract, ${ }^{9}$ marry, ${ }^{10}$ sue, or be sued in their own

3. "When a client's ability to make adequately considered decisions in connection with the representation is impaired, whether because of minority, mental disability or for some other reason, the lawyer sliall, as far as reasonably possible, maintain a normal client-lawyer relationship with the client." MOdel Rules of Professional Conduct Rule 1.14(a) (1983) [hereinafter MOdel RULES].

4. "[T]he authority to make decisions is exclusively tlat of the client and, if made within the framework of the law, such decisions are binding on his lawyer." MODEL CODE OF PROFEssional RESPONSIBILITY EC 7-7 (1980) [hereinafter MODEL CODE].

5. "An infant or person who is under the age of legal competence." BLACK's LAW Dictionary 899 (5th ed. 1979). This Comment uses the terms "minor" and "child" interchangeably.

6. Bank of the United States v. Ritclie, 33 U.S. (8 Pet.) 128, $145-46$ (1834) (holding legally ineffective an infant's consent to a conveyance).

7. See, e.g., CAL. Civ. Code $\S \S 60-70$ (Deering Supp. 1987); LA. Civ. CODE ANN. arts. 365 385 (West 1952 \& Supp. 1987) (both giving qualifying minors limited adult riglits); see also Katz, Schroeder \& Sidman, Emancipating Our Children-Coming of Legal Age in America, 7 FAM. L.Q. 211 (1973); Comment, The Emancipation of Minors Act: A California Solution for the Mature Minor, 12 U.C. DAVIS L. REv. 283 (1979).

8. For example, a Louisiana statute provides that consent to medical treatment by "a minor who is or believes liinself to be afflicted with an illness or disease, shall be valid and binding as if the minor lad achieved lis majority." LA. REv. STAT. ANN. § 40:1095(A) (West 1977).

9. See 2 S. Williston, A TReatise ON The LaW OF Contracts $\S$ 222-248 (3d ed. 1959); see also Edge, Voidability of Minors' Contracts: A Feudal Doctrine in a Modern Economy, 1 GA. L. REv. 205 (1967) (arguing that the contractual disability of minors is unjustified).

10. See, e.g., CAL. CIV. CODE $\S 4101$ (Deering 1984); see generally Wardle, Rethinking Marital Age Restrictions, 22 J. FAM. L. 1 (1983-1984) (survey and analysis of age restrictions on marriage). 
right. ${ }^{11}$ The United States Supreme Court has explained that "the constitutional rights of children cannot be equated with those of adults [because of] the peculiar vulnerability of children; their inability to make critical decisions in an informed, mature manner; and the importance of the parental role in child-rearing."12 Further,

[J]uveniles, unlike adults, are always in soine form of custody. . . . Children, by definition, are not assumed to have the capacity to take care of theinselves. They are assumed to be subject to the control of their parents, and if parental control falters, the State must play its part as parens patriae. $^{13}$

The normal presumption is that parents will function as substitute decisionmakers for their minor children. ${ }^{14}$ "This primary role of the parents in the upbrimging of their children is now estabhished beyond debate as an enduring American tradition."15 Parents thus have general authority to inake decisions concerning the medical, inoral, intellectual, and financial welfare of their children. This authority is founded on an acknowledgeinent of parental rights, ${ }^{16}$ and on a behief that parents can best determine, and are most likely to protect, the interests of their children. ${ }^{17}$

However, the presumption in favor of parental decisionmaking is rebuttable. "Parental autonomy ... is not absolute. The state is the guardian of society's basic values. Under the doctrine of parens patriae,

11. "In all suits brought against infants ... the duty of watching over their interests devolves in a considerable degree upon the court." Ritchie, 33 U.S. (8 Pet.) at 143-44.

12. Bellotti v. Baird, 443 U.S. 622, 634 (1979) (plurality opinion) (invalidating a Massachusetts law requiring parental consent for abortions by unmarried minors).

13. Schall v. Martin, 467 U.S. 253, 265 (1984) (citations omitted) (upholding a New York law prescribing pretrial preventive detention for juvenile suspects).

14. "[T]here is a presumption, strong but rebuttable, that parents are the appropriate decisionmaker for their infants." Bowen v. American Hosp. Ass'n, 106 S. Ct. 2101, 2113 n.13 (1986) (plurality opinion) (invalidating federal regulations requiring medical treatment for handicapped infants without parental consent); accord Prince v. Massachusetts, 321 U.S. 158, 166 (1944) ("the custody, care and nurture of the child reside first with the parents"); see also Weithorn, Children's Capacities for Participation in Treatment Decision-Making, EMERgING Issues IN CHILD Psychiatry AND THE LAW 22, 22 (1985) (typically, parents can and do make decisions in the "best interests" of their children).

15. Wisconsin v. Yoder, 406 U.S. 205, 232 (1972) (exempting Amish children from compulsory formal education beyond the eighth grade).

16. The United States Supreme Court has recognized the "fundamental liberty interest of natural parents in the care, custody, and management of their child." Santosky v. Kramer, 455 U.S. 745,753 (1982) (requiring "clear and convincing evidence" in proceedings to terminate parental rights); see also Stanley v. Illinois, 405 U.S. 645, 658 (1972) (unwed father entitled to a parental fitness hearing before the state can terminate his parental rights); Ginsberg v. New York, 390 U.S. 629, 639-43 (1968) (upholding a ban on the sale of sex-related material to minors); Pierce v. Society of Sisters, 268 U.S. 510, 534-35 (1925) (compulsory public school attendance unreasonably interferes with parental right to direct the upbringing and education of children).

17. "[H] istorically [the law] has recognized that natural bonds of affection lead parents to act in the best interests of their children." Parham v. J.R., 442 U.S. 584, 602 (1979) (leaving the decision to commit a child to a state mental institution largely with the parents). 
the state has a right, indeed a duty, to protect children. ... State officials may interfere in fainily matters to safeguard the child's health, educational developinent, and einotional well-being." 18

In some areas of decisioninaking, the interests of either the child or the state overcome the presumption that parents will make the best decision. Traditionally, government regulation has limited parental decisionmaking authority in the areas of child labor, ${ }^{19}$ infant marriage, ${ }^{20}$ compulsory education, ${ }^{21}$ and severe physical deprivation. ${ }^{22}$ Recently, parental authority has been limited im decisions concerning abortion and contraception, ${ }^{23}$ access to necessary inedical treatment, ${ }^{24}$ and possibly freedom from confineinent or commitment. ${ }^{25}$

The presunption im favor of parental decisionmaking can also be

18. In re Phillip B., 92 Cal. App. 3d. 796, 156 Cal. Rptr. 48 (1979) (affirming trial court's dismissal of state's petition to terminate parental rights), cert. denied, 445 U.S. 949 (1980); see Santosky, 455 U.S. at 766-67; see also Jefferson v. Griffen Spalding County Hosp. Auth., 247 Ga. 86, 274 S.E.2d 457 (1981) (per curiam) (awarding teinporary custody of unborn fetus to the state and ordering the mother to submit to a caesarean section prohibited by her religion).

19. See, e.g., Prince v. Massachusetts, 321 U.S. 158 (1944) (upholding conviction under child labor laws of a guardian who permitted a child to sell religious literature in public).

20. See, eg., People v. Benu, 87 Misc. 2d 139, 385 N.Y.S.2d 222 (Crim. Ct. 1976) (father convicted of child endangerment for arranging the marriage of his 13 year-old-daughter).

21. See Pierce v. Society of Sisters, 268 U.S. 510, 534 (1925) ("[n]o question is raised concerning the power of the State ... to require that all children of proper age attend some school").

22. See, e.g., People v. Pointer, 151 Cal. App. 3d 1128, 199 Cal. Rptr. 357 (1984) (convicting mother of child endangerment for causing her children's extreme malnourishment through strict adherence to macrobiotic diet); In re D. K., 245 N.W.2d 644 (S.D. 1976) (termination of parental custody due to child's ill health and squalid home conditions).

23. Bellotti v. Baird, 443 U.S. 622, 634 (1979) (striking down a statute requiring parental consent for unwed minors to have abortions); Planned Parenthood v. Danforth, 428 U.S. 52,74 (1976) (the state cannot give parents "an absolute, and possibly arbitrary, veto over the decision of the physician and his patient to terminate the patient's pregnancy"); see generally Note, The Minor's Right To Abortion And The Requirement Of Parental Consent, 60 VA. L. REV. 305 (1974) (discussing scope of a minor's right to privacy). The status of contraception is less clear. For an array of views on the right of minors to obtain contraceptives see Carey v. Population Services Int'l, 431 U.S. 678 (1977) (invalidating New York's ban on the sale of contraceptives to minors under 16).

24. See, e.g., Bowen v. American Hosp. Ass'n, 106 S. Ct. 2101, 2113 \& n.13; In re Phillip B., 92 Cal App. 3d. 796, 156 Cal. Rptr. 48 (1979), cert. denied, 445 U.S. 949 (1980); see generally, Bennett, Allocation of Child Medical Care Decisionmaking Authority: A Suggested Interest Analysis, 62 VA. L. REV. 285, 292-94 (1976) (discussing legislative provisions for minor consent to inedical treatment); Coinment, Minors' Rights To Medical Care, 14 J. FAM. L. 581 (1975-1976) (discussing statutory and case law approaches to minors' consent); Note, Choosing For Children: Adjudicating Medical Care Disputes Between Parents and the State, 58 N.Y.U. L. REV. 157, 160-66 (1983) (discussing judicial treatment of medical care disputes).

25. The United States Supreme Court acknowledged the due process rights of a minor subject to confinement for juvenile delinquency in In re Gault, 387 U.S. 1 (1967), but it has granted significantly less protection to juveniles "voluntarily" committed to state institutions by agreement of their parents, doctor, and the director of the institution. See Parham v. J.R., 442 U.S. 584 (1979); Secretary of Pub. Welfare v. Institutionalized Juveniles, 442 U.S. 640 (1979) (no formal adversary hearing required for the institutionalization of inentally ill children). For a scathing comparison of the two areas, see Shoenberger, "Voluntary" Commitment of Mentally Ill or Retarded Children: Child Abuse by the Supreme Court, 7 U. DAYTON L. REV. 1 (1981). 
rebutted if a conflict of interest exists between the members of the particular family. Such conflicts arise when, for example, a parent and child have competing financial interests in a will or trust, ${ }^{26}$ when they have potential tort liability to one another, ${ }^{27}$ when warring parents disagree with each other, ${ }^{28}$ or when a parent is accused of abusing, neglecting, or endangering a child. ${ }^{29}$

Once a child's parents are disqualified from substitute decisionmaking, the state, $\mathrm{m}$ its role of parens patriae, ${ }^{30}$ will generally make necessary decisions through the courts, legislatures, or appropriate agencies. Traditionally, the court has assumed the parens patriae role in adjudication concerning children. The judge was traditionally seen as a fatherly patriarch who protects the child, thereby alleviating the need for independent protection of the child's due process rights. ${ }^{31}$ Under this view, the court resolved disputes in accordance with its determination of the child's "best interest."32

Commentators have attacked the paternatistic approach as unfair because it fails to accord minors the respect and equitable treatment due all inembers of society. As the Supreme Court has stated, "[u]nder our Constitution, the condition of being a boy does not justify a kangaroo court."33 Professor Guggenheim has expanded the notion:

[C]onsistency and equity demand that [a] child be allowed to direct his own counsel in delinquency proceedimgs. . . . It would be both imconsistent and unfair to treat the child as a morally responsible actor who must suffer the consequences of his own delinquent acts and yet ... deny that he is autonomous enough to be capable or entitled to instruct counsel in the adjudication of those same acts. ${ }^{34}$

26. See, e.g., Cooper v. Liverman, 406 S.W.2d. 927 (Tex. Civ. App. 1966) (guardian ad litem should have been appointed to represent the minor's interests where they were adverse to the father's interests).

27. See, e.g., France v. A.P.A. Transp. Corp., 56 N.J. 500, 267 A.2d 490 (1970).

28. See, e.g., Palmore v. Sidoti, 466 U.S. 429 (1984) (the state has a substantial but not unlimited governmental interest in acting in the child's "best interests").

29. See, e.g., In re D.K., 245 N.W.2d 644 (S.D. 1976).

30. State management of infants' affairs traditionally has been based on the doctrine of parens patriae, which refers to the king's position as "father of his country." A seminal case, Eyre v. Countess of Shaftsbury, 24 Eng. Rep. 659 (Ch. 1722), reasons that the king has a duty to protect lunatics and children because they cannot take care of themselves. See Kleinfeld, The Balance of Power Among Infants, Their Parents and the State, 5 FAM. L.Q. 63, 66 (1971).

31. In re Gault, 387 U.S. 1, 26 (1967), rejects this traditional assumption.

32. "In common with most states, Florida law mandates that custody determinations be made in the best interests of the children involved." Palmore, 466 U.S. at 433 (1984). The best interest determination may be the ultimate issue in the case, such as in custody disputes, or may be a factor weighed against the interests of others. See id. ("The goal of granting custody based on the best interests of the child is indisputably a substantial government interest for purposes of the Equal Protection Clause.").

33. In re Gault, 387 U.S. at 28.

34. Guggenheim, supra note 2 , at 87. 
Children are less likely to become responsible, self-respecting citizens if unfairness deprives them of a sense of justice. ${ }^{35}$ Additionally, the paternalistic approach undermines the traditional American adversarial paradigm, under which the judge or jury makes the optimal decision after all parties in interest liave presented the issues from their own perspective and represented their interests selfishly, without balancing opposing considerations. $^{36}$ However, in cases that implicate their own interests, neither parents nor the state can present an unbiased view of the child's interest. $^{37}$

The judicial proceedimg may imphicate conflicting parental interests. The parents' personal desires, such as seeing the child punished, or receiving or avoiding custody or other parental responsibilities, may also affect the litigation. Particular parental beliefs on issues such as abortion and medical treatment may also bear on the parents' attitude. Despite their relevance, tliese parental beliefs may not be shared by the child and may be contrary to the child's interests. One domestic relations court stated:

[W] have long noted in the reported cases dealing with children's rights, a tendency to identify them with parental rights, i.e., to regard them as identical. This is quite understandable, but not always correct. One doesn't have to work in a family court very long to learn that in countless circumstances a juvenile's rights and interests . . . are at sharp variance with those of his parents. ${ }^{38}$

The state, through its representatives such as child welfare agencies, social workers, and public prosecutors, is also unlikely to present an uncompromised view of the child's interests ${ }^{39}$ that is free of institutional or professional biases and interests. In assessing the interests of a particular child, a government representative must consider the needs of the system, such as admmistrative requirements and costs, and the needs of

35. "The idea of fairness is part of the fabric of the doctrine of justice, and the sense of what's fair and unfair emerges in childhood. . . . Children must be treated fairly if we want them to mature into responsible adulthood." H. FOSTER, A "BILL OF RIGHTS" FOR CHILDREN xi (1974).

36. See American Bar Association Joint Conference on Professional Responsibility, Professional Responsibility: Report of the Joint Conference, 44 A.B.A. J. 1159, 1160 (1958).

37. See supra text accompanying notes $26-29$.

38. In re Clark, 21 Ohio Op. 2d 86, 87, 185 N.E.2d 128, 130 (1962) (ordering a blood transfusion for the child against the parents' religious beliefs).

39. It may at first seem strange ... to separate the interests of the child from those of the state. But the state has interests other than those inherent in its parens patriae role, and these other interests may conflict with those of the child in a partieular case. For example, the state has a strong interest in maintaining family autonomy. . . . A seeond interest of the state is the exercise of its police power....

At least two other key interests of the state-administrative efficiency and fairnessmay conflict with the interests of the child ....

Areen, Intervention Between Parent and Child: A Reappraisal of the State's Role in Child Neglect and Abuse Cases, 63 GEO. L.J. 887, 893-94 (1975) (footnotes omitted). 
the class of children as a whole. ${ }^{40}$ These are, of course, important factors, but they should properly be considered by the judge rather than the child's advocate. In addition, a government employee or agency representing a child may be constramed by government policy. ${ }^{41}$ Finally, scholars have accused government representatives such as social workers of a bias towards a white, middle-class socioeconomic norm, which prejudices their determination of the child's imterests. ${ }^{42}$ Increasingly, scholars and practitioners have argued $\mathrm{m}$ favor of separate representation of children as a solution to these problems. ${ }^{43}$

Even if the above concerns are not borne out in the majority of cases, independent representation of children is justified as a precaution in situations where conflicts of interest are particularly likely or a wrong decision is particularly destructive. Such representation creates a "safety net" that protects the child where, for instance, there are allegations of serious child abuse or where a minor is subject to lengthy confinement for delinquency. ${ }^{44}$

\section{II}

\section{EMERGENCE OF INDEPENDENT REPRESENTATION}

Concerns about the traditional approach have catalyzed support for the use of independent representation for children. ${ }^{45}$ The United States Supreme Court held in In re Gault that a right of counsel exists when delinquency proceedings threaten a child's liberty. ${ }^{46}$ Fifteen-year-old Gerald Gault, charged with inaking lewd telephone calls, was coinmitted to the Arizona State Industrial School as a juvemile delinquent until he

40. Although the judge, the department of social services, and the prosecutor are usually expected to be guided by considerations of the best interests of the child, fiscal concerns, public pressure, and professional loyalties may overshadow the child's interests. Administrative delays and oversight may be accepted without criticism. Time limitations and staff turnover can prevent an adequate exploration of the child's problems and possible solutions.

Ramsey, Representation of the Child in Protection Proceedings: The Determination of Decision-Making Capacity, 17 FAM. L.Q. 287, 292 (1983) (footnotes omitted).

41. See, e.g., Noe v. True, 507 F.2d 9 (6th Cir. 1974) (district court must consider appointment of a guardian ad litem for a pregnant minor challenging a state statute prohibiting her legal guardian, the State Department of Human Resources, from consenting to or providing payment for an abortion.)

42. See, e.g., Smith v. Organization of Foster Families for Equality \& Reform, 431 U.S. 816, 834 (1977) (documenting scholarly debate concerning class bias in family law) [hereinafter OFFER].

43. For a comprehensive list of articles concerning separate representation, see Note, Lawyering For the Child: Principles of Representation in Custody and Visitation Disputes Arising From Divorce, 87 YALE L.J. 1126, 1127 n.7 (1978).

44. In re Gault, 387 U.S. 1 (1967) could be interpreted as a prohibition against taking judicial chances when a person's liberty is at stake.

45. See Note, supra note 43 , at $1127 \&$ n.7 (independent representation for children "has received widespread support").

46. In re Gault, 387 U.S. 1 (1967). 
reached n1ajority. ${ }^{47}$ The United States Suprenie Court reversed the denial of his habeas corpus petition on due process grounds, including the lack of notice of his right to counsel. ${ }^{48}$

In litigation other than for dehinquency proceedings, support for and use of separate representation varies. ${ }^{49}$ But regardless of whether separate representation for children is either necessary or justified, ${ }^{50}$ it exists and is nicreasing. Clarifying the role that such attorneys should play is therefore necessary and desirable.

Currently, there is no definitive articulation of the appropriate role of a child's representative. The American Bar Association Model Code Of Professional Responsibility Ethical Consideration (EC) 7-11 declares: "The responsibilities of a lawyer inay vary according to the intelligence, experience, niental condition or age of a client." ${ }^{\text {11 }}$ EC 7-12 goes on to advise:

Any mental or physical condition of a client that renders him incapable of making a considered judgment on his own behalf casts additional responsibilities upon his lawyer. Where an incompetent is acting through a guardian or other legal representative, a lawyer must look to such representative for those decisions which are normally the prerogative of the client to make. If a client under disability has no legal representative, his lawyer may be compelled ... to make decisions on behalf of the chient. If the chent is capable of understanding the matter in question or of contributing to the advancement of his interests, regardless of whether he is legally disqualified from performing certain acts, the lawyer should obtain from him all possible aid. If the disability of a client and the lack of a legal representative compel the lawyer to make decisions for his client, the lawyer should consider all circumstances then prevailing and act with care to safeguard and advance the interests of his client. ${ }^{52}$

47. Id. at $4-8$.

48. Id. at 61 .

49. For example, some form of separate representation for children in divorce custody disputes has been instituted in approximately half the states, see Note, supra note 43 , at $1127 \&$ n. 8 (24 states have made some provision for independent representation), and is authorized by the UNIFORM MARRIAGE AND DIVORCE ACT § 310, 9A U.L.A. 172 (1979). In addition, some form of guardian ad litem is required to receive federal funds under The Child Abuse Prevention and Treatment Act, 42 U.S.C. 5103(b)(2)(G) (1983). As of 1982, 22 jurisdictions required separate representation in protective proceedings, while an additional 15 jurisdictions permitted it. See Kelley \& Ramsey, Do Attorneys for Children in Protection Proceedings Make a Difference-A Study of the Impact of Representation Under Conditions of High Judicial Intervention, 21 J. FAM. L. 405,408 n.9 (19821983). In constitutional class actions, a parent or guardian may hire an independent advocate for the children or the court may appoint one, but the Supreme Court has not yet articulated any general right to independent representation for minors.

50. A detailed treatment of the pros and cons of independent representation for children is beyond the scope of this Comment. For a detailed discussion of that issue, see Guggenheim, supra note 2.

51. MODEL CODE, supra note 4, EC 7-11.

52. Id., EC 7-12. 
Model Rule of Professional Conduct 1.14(a) addresses the problem directly but provides only superficial guidance. ${ }^{53}$ The Model Rule fails to explain how to determme when not to treat a minor as a normal chent or how the child-client should then be treated.

This lack of guidance has resulted in children's attorneys making independent subjective decisions about their role in the litigation. In some cases, attorneys theoretically representing a child's interest advocate their own view of what is "right," even if it directly conflicts with the expressed desires of the child.

For example, im Smith v. Organization of Foster Families For Equality and Reform, ${ }^{54}$ several foster parents hired an attorney to represent them and their foster children in a class action..$^{55}$ They sought to require the Department of Social Services to hold hearings before the children could be taken froin them. ${ }^{56}$ The attorney informed the parents and the court that she considered the children to be her primary clients and that she wished to remain their attorney if not permitted to represent both parents and children. ${ }^{57}$ The court denied her request and appointed an independent attorney to represent the children. ${ }^{58}$ The children's attorney did not conduct any investigation of the interests or desires of the plamtiff class. ${ }^{59}$ Instead, based on her previously established faith in New York's foster care system, she filed an answer to the complaint and ahgued herself with the defendants, putting herself in direct conflict with the stated wishes of the nained plaintiffs. ${ }^{60}$

The lack of any check on such autonomous decisionmaking by children's attorneys injects a degree of arbitrarmess into the judicial paradigm. Moreover, the decisions made by the attorney, unlike those made by a court, generally are not subject to appellate review. "[G]iving counsel to young children introduces a critical element of arbitrariness into our legal system. With the child's attorney acting as a third party litigant ... hike cases no longer come out alike." ${ }^{61}$ Consequently, scholars and practitioners increasingly debate not only the utility and desirability of separate representation for children, but also the acceptabihity of vari-

53. MODEL RULES, supra note 3, Rule 1.14 .

54. 431 U.S. 816 (1977).

55. Id. at $818-19$.

56. Id. at 839 .

57. Chambers \& Wald, Smith v. OFFER, in IN The INTERest OF Children 82, 91 (R. Mnookin ed. 1985)

58. Id.

59. Id. at 93 .

60. Id. at 91-93 (detailing the conduct of the children's attorney in OFFER); See also Guggenheim, supra note 2, at 146 \& nn.302-04.

61. Guggenheim, supra note 2, at 77; see also Kelly \& Ramsey, supra note 49 , at 411-16 (confusion surrounds appropriate role of attorney as guardian ad litem). 
ous roles for the child's attorney. ${ }^{62}$

Some have suggested the role of passive investigator-who does not advocate but merely informs. ${ }^{63}$ Such an attorney investigates the circumstances of the case and presents objective facts to the court, but does not offer opinions or advocate a particular outcome. The Supreme Court approved the use of a neutral factfinder, although not necessarily an attorney, to aid commitment decisions:

[T] he risk of error inherent in the parental decision to have a child institutionalized for mental health care is sufficiently great that soine kind of inquiry should be made by a "neutral factfinder" to determine whether the statutory requirements for admission are satisfied. ... That inquiry must carefully probe the child's background using all available sources, including, but not limited to, parents, schools, and other social agencies. Of course, the review must also include an interview with the child. ${ }^{64}$

However, a central problem with the role of neutral factfinder is that it conflicts with an attorney's duty to represent her client zealously ${ }^{65}$ and behave as an advocate. ${ }^{66}$ The role of neutral factfinder is also criticized as having insufficient utility to justify the attending invasion of faunilial privacy. ${ }^{67}$ The sahent point is that whether or not the factfinder is of substantial use in the hitigation, she is not performing the duties of an attorney. ${ }^{68}$ The Supreme Court iniplicitly supported this observation by acknowledging that sucl a neutral factfinder need not be "law trained." 69

A second approach would be for the child's representative to act as an additional advocate for the position of a government representative or

62. See, e.g., Areen, supra note 39, at 932-37 (suggesting a model for state intervention in cases of child abuse or neglect); Bricker, Children's Rights: A Movement In Search of Meaning, 13 U. RicH. L. REV. 661, 665, 682 (1979) (discussing roles of attorneys as enforcers of children's rights and as champions for children); Guggenheim, supra note 2, at 100-07 (arguing that independent representation can undermine the adversary process when children are too young to direct their attorney's behavior); Mlyniec, The Child Advocate in Private Custody Disputes: A Role in Search of a Standard, 16 J. FAM. L. 1, 16-17 (1977-1978) (attorneys should attempt to effectuate the child's wishes and view relationship from traditional attorney-client perspective, although standards are uncertain); Ramsey, supra note 40, at 288 (attorney should represent child's wishes when possible).

63. The New York Legal Aid Society took this position in the MANUAL FOR NEW ATTORNEYs 217-18 (1971), as well as advocating it as an option where the child-client is not capable of considered judgment and does not have a guardian ad litem. Standards RElating to Counsel for Private Parties Standard 3.1(b)(ii)[c] (1980).

64. Parham v. J.R., 442 U.S. 584, 606-07 (1979) (citations omitted).

65. MODEL CODE, supra note 4, EC 5.1; see also id. EC 7-1 ("[t]he duty of a lawyer, both to his client and to the system, is to represent his client zealously within the bounds of the law").

66. "The attorney is ... a an advocate whose role is to represent the child's interests." UNIF. MarRiage \& Divorce ACT § 310, 9A U.L.A. 172-73, Commissioners' Note (1979).

67. Guggenheim, supra note 2, at 109, 121-22 (role of neutral investigator may violate family's right to privacy).

68. "When courts and commentators propose that children be given [factfinders], they are really proposing a new form of court-ordered discovery; they are not, however, increasing the legal representation of young children by one iota." Id. at 108.

69. Parham, 442 U.S. at 607. 
parent. For example, in one view, "Gault reaffirms the right of a child to have his own parents make decisions . ..."70 However, this approach is generally dismissed as redundant and lacking utility, since neither parents nor government can be truly independent and so may not necessarily act in the child's best interest. ${ }^{71}$ In addition, the approach conflicts with the ethical prohibition against allowing the desires of third parties to dilute a lawyer's loyalty to her chent. ${ }^{72}$

According to a third approach, the child's attorney is a "champion"73 who advocates her own conception of the child-chent's best interest. Professor Guggenhemi criticizes this approach for usurping the function of the judge or jury ${ }^{74}$ as well as being redundant and arbitrary. Guggenheim argues that a champion is redundant because typical hitigation involving children, such as custody disputes, contains only two possible positions. ${ }^{75}$ According to Guggenheim, since each position is already represented by a parent, the chainpion can only advocate a position already represented. ${ }^{76}$ Guggenheim asserts that the existence of an extra champion for one side destroys the balance of the adversary process and may distort a judge's evaluation of the evidence if she gives undue weight to the chainpion's opinion. ${ }^{77}$ However, the element of arbitrariness depends upon Guggenheim's assumption that the champion inakes subjective judgments. To the extent that attorneys are guided by established procedures and exphicit factors to determine the child's position, that arbitrariness is reduced, if not eliminated. Most importantly, the chainpion approach fails both to speak for children and to expand their rights. $^{78}$ In sum, the basic coinplaint is that it is simply outside the role

70. J. GoldSTEIN, A. FREUd \& A. SOLNIT, BeFore THE BEST INTERESTS OF THE CHILd 129 (1979).

71. Ramsey, supra note 40 , at 293 (parents cannot be expected to represent the child's best interests when their interests conflict); see supra text accompanying notes 37-42.

72. MODEL CODE, supra note 4, EC 5-1 provides:

The professional judgment of a lawyer should be exercised, within the bounds of the law, solely for the benefit of his client and free of compromising influences and loyalties.

Neither his personal interests, the interests of other clients, nor the desires of third persons should be permitted to dilute his loyalty to his client.

(footnote omitted). EC 5-21 adds: "The obligation of a lawyer to exercise professional judgment solely on behalf of his client requires that he disregard the desires of others that might impair his free judgment."

73. See Guggenheim, supra note 2, at 100 \& n.114 (describing the conceptual role of a champion).

74. Id. at 102-03 (champions are redundant because they necessarily color their findings and cannot be neutral).

75. However, modern custody decisions often provide for various forms of shared custody that could be advocated.

76. Guggenheim, supra note 2, at 103-04.

77. Id. at 104-06.

78. See Bricker, supra note 62 , at $691-93$ (provision of a champion decreases children's influence and will not increase their welfare). 
of an attorney to represent his own views rather than those of his client. ${ }^{79}$

The fourth role commonly advocated is that of a classic "mouthpiece" for the child, who advocates only the child's own expressed desire or opinion. A nuniber of scholars identify this function as a child attorney's only legitimate role:

[A]n attorney should be provided only in cases where the child has a stated preference regarding the issue....

By performing his duties in the more traditional manner, the child advocate can best preserve the principles of mimimal outside intervention into the private family sphere while protecting the child's right, as an individual, to participate in legal matters affecting the child's life. ${ }^{80}$.

Others have identified the duties of a mouthpiece as the child's attorney's minimum or imitial role. ${ }^{81}$ This position also conforms most readily to the American Bar Association's general paradigm of attorney-client relations. $^{82}$

Regarding child custody disputes, it has been said that "the primary function of representation should be to place children with their preferred future guardian." 83 The child's attorney gives the child a voice in the decision affecting him, rather than making a subjective determination of the child's interests. But advocating children's rights by giving minors a voice in decisions affecting their lives must be distinguished from advocating children's welfare, which simply adds an additional outside opinion. $^{84}$

The possibility that the child may not be able to express a clear, uninfluenced and competent opimion complicates the task of representing the child-chient's wishes. ${ }^{85}$ The difficulty with the "mouthpiece" approach is to determine how far it is "reasonably possible"86 to treat the

79. The Standards Relating to Counsel for Private Parties Commentary states that an attorney's view should not be substituted for that of a client capable of considered judgment, Standard 3.1(b) commentary at 81, and the MODEL CODE, supra note 4, EC 7-24, prohibits an attorney from expressing his personal views to the judge.

80. Mlyniec, supra note 62 , at 16 . Other scholars assert that an attorney's duty is to advocate the outcome desired by his child-client if the child is at least seven years of age. Guggenheim, supra note 2, at 82-93; Ramsey, supra note 40 , at 320 . Guggenheim further asserts that if the child is under seven he should be presumed incapable of directing the proceeding and generally should not be assigned independent representation. Guggenheim, supra, at 93-117.

81. See, e.g., Comment, "Mom, Dad, I Want to Introduce My Lawyer": The Development of Child Advocacy in Family Law, 29 S.D.L. REv. 98, 105 (1983) (attorney should bring child's wishes to the court's attention).

82. See supra notes 65 and 72.

83. Bersoff, Representation for Children in Custody Decisions: All That Glitters is not Gault, 15 J. FAM. L. 27, 29 (1976-1977).

84. Bricker, supra note 62 , at $664-66$.

85. Genden, Separate Legal Representation for Children: Protecting the Rights and Interests of Minors in Judicial Proceedings, 11 HARV. C.R.-C.L. L. REV. 565, 588 (1976) (children's expressed views may not reflect their actual desires).

86. MODEL RULES, supra note 3, Rule 1.14. 
cliild as a regular client and what is to be done when that limit is reached. Model Rule 1.14 is flawed because it does not articulate a standard for determining when the child should not be treated like otlier clients or how the case should be directed when the child is not treated like a normal client. Part III will address tliese issues.

\section{III}

\section{REPRESENTING A MINOR}

Each of the proposed roles for a child's independent counsel possesses some degree of utility, but none articulates a role which is both professionally legitimate and functional in a range of situations. The ABA Model Rule 1.14(a) provides that: "[T]lie lawyer shall, as far as reasonably possible, maintain a normal chent-lawyer relationslip with the chent." 87 Unfortunately, the Model Rules do not identify the boundaries of what is "reasonably possible" or provide any useful guidance for what is to be done when it is not possible to maintain a normal lawyerclient relationship.

Part III of this Comment is devoted to answermg two questions: To what extent should an attorney be directed by her child-chent; and how should the case be directed when that limit is reaclied? This Comment concludes that an attorney should advocate the position desired by her client if the court determines that the child possesses sufficient maturity to comprehend the circumstances of the case, the crucial issues, and the probable consequences of the available positions on those issues. If the court determines that the child does not possess the requisite degree of maturity, the child's attorney should act under the doctrine of substituted judgment to approximate the decision that the child would want if he were mature.

\section{A. An Attorney's Role Is To Speak for Her Client}

An attorney's purpose and professional duty is to represent the interests of a client according to that client's point of view. ${ }^{88}$ This observation is self-evident under most circumstances and yet is blatantly ignored under proposed formulations of the role of independent counsel for minors. If an interested party is entitled to an attorney, surely it is not merely to counsel limi, but also to speak for limi to the court and to other parties. ${ }^{89}$ Independent counsel for a minor is no less obligated to speak for the child-client:

[W] hen a child needs [an independent representative], he needs an advo-

87. Id.

88. See supra notes 4 and 65 .

89. This view is supported by the tenets of professional responsibility. See supra note 65 . 
cate-someone who will plead his cause as forcefully as the attorneys for each competing custody claimant plead theirs. The basic premise of the adversary system is that the best decision will be reached if each interested person had his case presented by counsel of unquestionably undivided loyalty. 90

This view is in accordance with the ABA Model Rules directive that an attorney is to treat a minor as a regular client ${ }^{91}$ and the Model Code directive that an attorney is to obtain all possible aid in decisioninaking from the client even if the chent is under a legal disability such as minority. ${ }^{92}$

The attorney thus has an ethical responsibility to be bound by, and speak for, her client. In contrast, the court is not bound by the child's view, nor does the child's position predetermine the ultimate outcome of the hitigation. ${ }^{93}$ The judge or jury is still obligated to consider the other interests involved and the evidence supporting those interests. In this way, the views of all interested parties are advocated and the court or jury retains its role of making the final determination, whether that determination is of the child's "best interest" or otherwise. ${ }^{94}$

This Comment proposes that Model Rule 1.14 be extended by the addition of a new section concerning the professional responsibilities of independent counsel for mimors. The proposed section would be specifically directed toward attorneys appointed or retained to represent children who are without an unbiased guardian ad hitem to direct their attorneys.

\section{Proposed Extension of Model Rule 1.14:}

(c) If the chent is a minor who is not represented by an unbiased guardian ad litem, the lawyer shall seek a judicial determination of whether the client is competent to direct his attorney. If the court determines that the client is sufficiently mature to direct the case, his lawyer shall maintaim a normal attorney-chent relationship with the minor.

(1) The court shall make an individual determination of the particular child's inaturity and competence to direct his counsel in the case at issue. The court may, however, utilize rebuttable pre-

90. Veazey v. Veazey, 560 P.2d 382, 390 (Alaska 1977).

91. MODEL RULES, supra note 3, Rule 1.14.

92. "If the client is capable of understanding the matter in question or of contributing to the advancement of his interests, regardless of whether he is legally disqualified from performing certain acts, the lawyer should obtain from him all possible aid." MODEL CODE, supra note 4, EC 7-12.

93. Besharov, Representing Abused and Neglected Children: When Protecting Children Means Seeking the Dismissal of Court Proceedings, 20 J. FAM. L. 217, 236 (1981-82) (even wishes of sufficiently mature child are not necessarily binding upon the court).

94. See id. at 236-39 (presence of independent advocate for child assures that child's view will be heard in making final decision). 
sumptions concerning typical ages at which minors possess the requisite maturity to make competent decisions on various issues.

(2) If the court determines that the minor lacks sufficient maturity to direct the case, the lawyer should act under the doctrine of substituted judgment to approximate the decisions the minor would make if competent to direct the case. In making this determination, the lawyer should first consider all information and evidence that can be obtained from the minor, and then if necessary, the lawyer should consider information from outside sources including individuals who are personally acquainted with the particular child, professional authorities in the area, and the views of mature persons previously in the client's position.

\section{B. It Is Not Always Reasonably Possible To Maintain a Normal Attorney-Client Relationship}

At some point, the wislies of a child-client should no longer bind his attorney. Altliougli one could take tlie extreme position tliat the attorney sliould follow any desire expressed by a child-client, this position ignores tlie inescapable fact that children are different from adults. ${ }^{95}$ Children are not ouly especially susceptible to the dangers of duress and undue influence, ${ }^{96}$ but may be further liandicapped by their immaturity. ${ }^{97}$ In order to determine tlie extent to which the child's opimions should bind the attorney in accordance with Model Rule 1.14, some stricter test is necessary to ensure that the child is expressing a legitimate opiunon. ${ }^{98}$ Children inay fail to comprehend crucial concepts, issues, or the possible consequences of their decisions. They inay also fantasize or be prone to indecisive or inconsistent beliavior. ${ }^{99}$ As a counselor, the attorney must advise and lielp the child to understand not only what his clioices are, but also the potential results of those choices. As an advocate, tlie attorney inust make or obtain some determination as to wlien a

95. Bellotti v. Baird, 443 U.S. 622, 634-35 (1979); see also J. WESTMAN, CHILd AdvocaCY: New Professional Roles For Helping Families 251-57 (1979) (discussing legal use of three child development concepts: age grading based on changing capacity, psychological best interest standard with an implicit promotion of a child's development, and the critical importance of time in a child's life).

96. "A child of tender years is easily influenced." Obey v. Degling, 37 N.Y.2d 768, 771, 337 N.E.2d 601, 602, 375 N.Y.S.2d 91, 93 (1975).

97. See Bellotti, 443 U.S. at 633-34.

98. See Ramsey, supra note 40 , at 305-06.

99. The strength of the various factors limiting competence depends on the issues involved and the decision required. For example, in custody suits, the child (other than an infant) often has the best knowledge about his parents' parenting abilities and practices, but there exists a strong danger of undue parental influence. In contrast, when considering various tort settlement options, the child lacks the sophistication and knowledge necessary to make the financial decisions involved, but there exists little danger of undue parental influence. 
child's utterances could not reasonably be presented to the court as the child's position.

Two possible types of standards, a chronological cut-off and a maturity requirement, have acquired supporters. ${ }^{100}$ This Comment argues that a form of maturity requirement provides both a more legitimate and a more effective means of classifying the quality of a child's opinion.

\section{Chronological Cutoffs}

Chronological cutoffs provide a simple and clear classification for many rights and privileges in our society. ${ }^{101}$ The chronological cutoff approach has received support from scholars in the field. ${ }^{102}$ However, its lack of functional relation to its purpose undermines the precision of this approach. For example, children do not instantly acquire increased powers of comprehension and judgment on their seventh birthday; instead they develop at dranratically different rates. ${ }^{103}$ Professor Zimring labels this factor "[t]he Problem of Individual Variation"104 and recommends determining the rights of minors through a combination of nethods: individual competence testimg, discretionary decisionmaking, and "agegrading," i.e., chronological cutoffs. ${ }^{105}$

Professor Zimring takes the driver's hicense qualification procedure as a model. The applicant must reach a certain minimum age, must generally, as a practical natter, have parental approval, and must pass a competence test. ${ }^{106}$ The flaw in this model is that it fails to present a convincing argument that age-grading offers any utility in deciding who "ought" to receive a driver's license. A chronological cutoff does not determine who is qualified to drive; it simply limits the occasions when sucli a determination must be made. Zimring asserts that age-grading operates as a limit on "weak" parental decisionmaking, ${ }^{107}$ but identifying

100. Gaylin, Competence: No Longer All or None in Who SPEAKS FOR THE CHILD: THE Problems Of Proxy Consent 27-31 (W. Gaylin \& R. Mackin eds. 1982); Siegel \& Hurley, The Role Of The Child's Preference in Custody Proceedings, 11 FAM. L.Q. 1, 1-6 (1977).

101. For example, minimum age requirements for drinking, driving, smoking, and voting. See eg., CAL. Bus. \& Prof. CODE $\$ 25658$ (West 1985) (sale of any alcoholic beverage to person under the age of 21 years is a misdemeanor); CAL. VEH. CODE $\S 12507$ (West Supp. 1987) (any person less than 18 but older than 16 years of age may apply for and receive driver's license); CAL. PENAL CODE $\S 308$ (West Supp. 1987) (sale of cigarettes to person under the age of 18 is a misdemeanor); CAL. ELEC. CODE $\S 17$ (West 1977) (must be 18 years of age or older to vote).

102. See Chambers, Rethinking The Substantive Rules For Custody Disputes In Divorce, 83 MiCH. L. REv. 477, 564 (1984); Guggenheim, supra note 2, at 82-109; Ramsey supra note 40, at 31016.

103. J. WESTMAN, supra note 95, at 72-74, 89; Ramsey, supra note 40, at 315 .

104. F. Zrmring, The Changing Legal World Of Adolescence 126 (1982).

105. Id. at 128.

106. Id. at $128-29$.

107. Id. at 129. 
the decisionmaking process as weak is possible only if it is known that the decisions that result are wrong. For example, the cutoff would not affect a "weak" parental decision to allow a wild and irresponsible sixteen-year-old alcoholic to drive, but would prevent a stable and mature fifteen-year-old from acquiring a license needed to retam a part-time job. The underlying theory of age-grading is that while it does not achieve the best possible decision im each imdividual case, the benefit of a clear and concise general standard outweighs the harm to that divergent competent child.

Thus, a chronological cutoff possesses procedural rather than substantive utihty. ${ }^{108}$ Under circumstances where the disqualified but competent percentage of minors is harmed only by the postponement of an undamaged privilege and the burden of accurate imdividual assessment is high, age-grading can be a valid and useful standard of decisionmaking. However, where the minor stands to lose a fundamental personal right, the convenience of a chronological cutoff comes at too high a cost. For example, in Bellotti v. Baird, ${ }^{109}$ unmarried pregnant minors sought to obtain abortions without parental consent. If the pregnant minors were automatically derried an abortion due to their age, without regard to their maturity, their fundamental right to decide whether to bear a child could be lost without any individual assessment of the circumstances. The denial of such a right inflicts a cost which cannot be compensated for by a later grant of autonomy. Therefore, $m$ these circumstances, an automatic chronological cutoff should not be applied. ${ }^{110}$

Nevertheless, age-grading can be useful as a rebuttable presumption to aid courts in making individual determinations of competence. ${ }^{111}$ Competence to make a particular type of decision would be presumed to exist at a certain age, although the presumption conld be rebutted by evidence of the individual child's competence or mcompetence. For example, minors who are at least fourteen could be presumed competent to choose their own gnardian. ${ }^{12}$ This system would allow individual competence to be the determinate factor, but would provide a guideline to check discretionary decisionmaking, as well as to simplify and expedite clear cases. Various chronological guidehnes, as opposed to cutoffs,

108. A chronological cutoff is the "tidiest" method but ignores the variation between individual children. Id. at 127.

109. 443 U.S. 622 (1979).

110. "[T] $]$ he peculiar nature of the abortion decision requires the opportunity for case-by-case evaluations of the maturity of pregnant minors." Id. at $643 \mathrm{n} .23$.

111. See, e.g., Ramsey, supra note 40 , at 320 (recommending a presumption that children over seven years of age are capable of decisionmaking in protection procecdings).

112. The Uniform Probate Code provides that a minor over the age of 14 may choose his own guardian unless the court determines that the particular decision is clearly not in the minor's best interest. UNIF. PROBATE CODE § 5-207 (1969). 
could be utilized to avoid the necessity of detailed individual determinations in each case. Such guidelines would be based on general norms, such as the fact that infants do not generally understand high finance and thus are not competent to make complex financial decisions, or that teenagers are generally competent to direct their attorneys' position in a custody dispute. Presumptive age-grading is thus a useful tool to aid a determination of a child's competence to make a particular decision. Therefore, although the use of a strict chronological cutoff is too inaccurate to justify the demial of the child's right to direct his own legal representative, age-based presumptions could be utilized as an element of a maturity assessment.

\section{Maturity Tests}

The use of maturity standards to determine when to defer to a minor's wishes has received support from a variety of sources. The American Bar Association advocates deferring to a client's wishes, depending on the chent's ability to make a "considered judgment."113 The cominon law has long utilized the maturity standard of "the age of mtelligent discretion," 114 which has been incorporated into modern statutes. ${ }^{15}$ In addition, the United States Supreme Court prescribed a maturity test in affording minors the right to decide to have abortions without their parents' consent. ${ }^{116}$ Therefore, the maturity or immaturity of the child-chent is the relevant factor in determining the child's competence to direct his attorney and should be expressly considered.

A maturity requirement, unlike a chronological cutoff, can be expressly tailored to fit the precise needs of the situation. An appropriate standard for such a requirement would be the ability to know and understand the relevant facts, options, and probable outcomes in a particular decision. An analogous standard is used to determine a testator's competence to make a will:

[T] he rule is generally accepted to be that a person is of sound mind for testamentary purposes if the person is able to understand "(1) [t]he nature and extent of his property, (2) [t]he persons who are the natural objects of his bounty, and (3) [t] he disposition which he is making of his property," and if he is "capable of (4) [a]ppreciating those elements in relation to each other, and (5) [f]orming an orderly desire as to the dispo-

113. ABa Standards Relating to Counsel for Private Parties Rule 3.1(b)(i) and (ii)[b] (1979) (child protective proceedings) [hereinafter ABA STANDARDS]; MODEL RULES, supra note 3 , Rule 1.14 .

114. See Siegel \& Hurley, supra note 100, at 1-6 (citing cases).

115. See, e.g., CaL. Clv. CoDE $\$ 4600$ (a) (West Supp. 1987) ("[i]f a child is of sufficient age and capacity to reason so as to form an intelligent preference as to custody, the court shall consider and give due weight to the wishes of the child").

116. Bellotti v. Baird, 443 U.S. $622,643-44$ \& n.23 (1979). 
sition of his property."117

However, a testator need only have the capacity to make an informed decision, whereas an attorney has a responsibility to advise her chent in a manner that fosters an actual informed decision.

The salient point of the test is to ensure that the child-client understands why he is being asked to make a decision, what reasonable options exist, and how his choice is likely to affect himself and others. A child will thus be coinpetent to make different decisions at various stages of maturity, dependmg upon the complexity and sophistication of the issues involved.

For example, in order to formulate the child's position in a custody dispute, it may be sufficient if the child understands that his parents are going to hive in separate hoines, that he will be able to hive with one or the other but not both, that each parent wants custody of him, and that the person making the decision is interested in his preference. If a young child is able to comprehend this situation and express a preference, then his choice of custodian should be advocated vigorously by his attorney, leaving it to the court to determine the weight that his preference should be given $m$ the ultimate custody decision. ${ }^{118}$

In contrast, the same child may not be equally competent to reach a considered judgment concerning proposed medical treatments. A young child may be unable to comprehend the possibility of death, or to conceptualize hiving with or without a medical handicap. If the child is unable to understand these concepts and they are critical elements of the options between which he must choose, then he is not competent to make the decision. While children, like adults, may rely on legal, financial or medical advice, the child-chient must be able to assimilate critical information and form his own reasoned decision im order to direct his case.

The child-chent's competence could be determined either by an attorney's individual assessment or by a court hearing. Although attorney assessments have their advantages, a court determination is preferable, given the goal of reducing arbitrariness.

The major advantage of a determination by the attorney is that she will generally have spent a substantial amount of time both with the child and speaking with those who know him. Thus, the attorney will generally be better informed about the particular child than the judge and the-

117. E. Scoles \& E. Halbach, Decedents' Estates ANd Trusts 545 (3d ed. 1981) (quoting I. ATKINSON, HANDBOOK OF THE LAW OF WILLS $\$ 51$ (2d ed. 1953)).

118. Obviously, imposing ethical constraints on a child's independent counsel will not make decisions in custody suits or any other type of case predictable. However, it will perform the dual functions of maintaining the proper functioning of the adversarial system and of reducing the degree of arbitrariness. 
oretically in a better position to judge his general inaturity and specific understanding of the situation.

However, a private assessinent by the attorney is open to the danger that the attorney, either consciously or unconsciously, will judge the child to be incompetent simply because she disagrees with the child's substantive decision. The problem is exacerbated by the possibility that the child's attorney might be inflexibly committed to specific positions regarding a child's competence, autonoiny and best interests. "[C]hild savers' ... are really seeking to mipose on children ... what they themselves view as beneficial to [the children's] welfare." 119 The danger of this behavior is that such an attorney steps outside of her role as the child's representative and thus destroys the adversary paradigm.

Correspondingly, the judge presiding over a court hearing inay also base her determination of a child's competence on her personal biases. However, a judge's position in the adversarial paradigm is to inake fair, objective determinations based on the information presented, whereas attorneys are to take a definite position and defend it at all costs. Objectivity could be additionally increased if the child's inaturity was evaluated by a different judge than the one presiding over the litigation.

A contrasting danger of a court determination is that the hearing could becoine a token formality, with all children who are capable of verbalizing a desire automatically being declared coinpetent to direct their attorneys. But, given the traditionally paternalistic American attitude towards children, ${ }^{120}$ it is unlikely that inany judges would be so eager to afford children autonomy.

A third danger is that individual judicial determinations could constitute a serious administrative burden. However, courts could develop general standards and rebuttable presuinptions to expedite such coinpetency determinations. ${ }^{121}$ Indeed, in one of its inost common settings, a probate proceeding, the court lacks even the opportunity of interviewing the testator whose competence is in question. This development of general standards by the courts has the added advantage of promoting general consistency in decisionmaking.

In suin, a court determination is preferable to the attorney's assessinent of the child's competence to direct his case because a court determination is more likely be an accurate and unbiased assessment. Once the child-client has been judged inature enough to inake his own decision in

119. Bricker, supra note 62 , at 665 .

120. See, e.g., D. VANDeVeer, Paternalistic INTERvention: The Moral Bounds ON BenEvolence 423 (1986) ("Paternalistic intervention seems proper and fitting when we consider ... raising and caring for our children.")

121. See, e.g., the rebuttable presumption that children over 14 are competent to choose their own guardian, supra note 112. 
the matter, his attorney is then as bound to follow his wishes as she would be with any other chient. "Although [the attorney] may strongly feel that the client's choice . . . is unwise, and perhaps be right in that opinion, [her] view may not be substituted for that of a client who is capable of considered judgment . . . ."122 Her disagreenient with the content of the child's decision is irrelevant once it is determined that it was arrived at in a rational, mature manner. ${ }^{123}$ The difficult case arises when the child-chent is not capable of mature, considered judgment.

\section{Representation of an Immature Client}

In an ideal world, a chent would always direct his attorney and an attorney would always advocate the client's express wishes. However, since this paradigm is not always available for the attorney representing a young child, it is necessary either to formulate a substitute model or to declare the situation hopeless. ${ }^{124}$

Professor Guggenheim takes the position that mdependent counsel cannot truly represent a child if the child is too young to direct the case, and therefore courts and legislatures should be cautious in appointing counsel for young children. ${ }^{125}$ However, despite the regrettable fact that an attorney cannot always maintain "normal" relations with the child, nor imitate sucl relations with certainty or exactitude, the estabhished tenets of an attorney's professional responsibility ${ }^{126}$ are best served by an attempt to approximate a normal attorney-chent relationship. Furthermore, given the practical reahty that separate representation for children is desired and practiced, a workable solution must be found to allow an attorney representing an immature minor to speak for her client in a fashion as consistent as possible with the American adversarial paradigm. ${ }^{127}$

The unfortunate fact that a client is too young to direct the case does not relieve his attorney of the obhgation to remain uninfluenced by the desires of third parties. ${ }^{128}$ Nor does it modify the dangers of an attorney advocating a purely personal and subjective opmion of what is best. Rather, the attorney in these circunistances must strive to formulate a position based on what the child-client would advocate if able to compre-

122. ABA STANDARDS, supra note 113, Rule 3.1(b) comment.

123. "The attorney's personal feelings regarding that choice should not take precedence over the [child-client's] stated position." Mlyniec, supra note 62, at 16 (footnote omitted).

124. See, e.g., Guggenheim, supra note 2, at 154-55.

125. Id.

126. See supra notes $65 \& 72$.

127. See supra notes 4 \& 72.

128. An attorney must exercise his judgment "solely for the benefit of his client and remain free of compromising influences and loyalties." MODEL CODE, supra note 4, EC 5-1; see also supra note 72 (text of EC 5-1). 
hend the situation and express himself adequately. In Rawls's words, to act justly "[w]e must choose for others as we have reason to believe they would choose for themselves if they were at the age of reason and deciding rationally." 129 When a child lacks the maturity to reach a competent decision, the attorney should substitute a judgment of what that child would desire. ${ }^{130}$ This substituted judgment, which "commends itself simply because of its straightforward respect for the integrity and autonomy of the individual," 131 focuses not on what the attorney thinks the child should want, but on what the particular child, if mature, would want.

The doctrine of substituted judgment has already been used in the area of medical treatment consent. ${ }^{132}$ However, the use of the doctrine of substituted judgment for immature minors would differ in several respects from its use in the medical treatment of incoinpetent or unconscious patients. One frequent difference is that attorneys may consult individuals who were formerly in the position of the child, but who have now attained sufficient maturity to give competent opinions about their past experiences. In addition, even if minors are not fully competent to direct their attorneys, they are nevertheless frequently able to provide their attorneys with substantial relevant inforination about their interests and desires. The child's attorney inust also consider the rainifications of the fact that the child-client will one day be a mature and competent adult who will be in a position to look back upon the decisions inade on his behalf and who must hive with those decisions. Finally, the doctrine in this context differs in that the substituted judgment that is reached will not necessarily be the final determination in the case. In other areas, the determination of what the incompetent person would want if competent

129. J. RAWLS, A THEORY Of JUSTICE 209 (1971).

130. "The right to act for an incompetent has been recognized as the doctrine of substituted judgment' and is broad enough to cover all matters touching on the well-being of legally incapacitated persons. The doctrine has been recognized in American courts since 1844." Hart $v$. Brown, 29 Conn. Supp. 368, 370, 289 A.2d 386, 387 (1972).

131. Superintendent of Belchertown State School v. Saikewicz, 373 Mass. 728, 751, 370 N.E.2d 417, 431 (1977).

132. "The means developed by the courts to afford th[e] right [to refuse extraordinary lifesustaining measures] to incompetent persons is the doctrine of 'substituted judgment.' Under this doctrine close family members or legal guardians substitute their judgment for what they believe the ... incompetent persons, if competent, would have done under the circumstances."

John F. Kennedy Memorial Hosp., Inc. v. Bludworth, 452 So.2d 921, 926 (Fla. 1984); see also In the Matter of Moe, 385 Mass. 555, 432 N.E.2d 712 (1982) (guardian of mentally incompetent person could use substituted judgment in order to act on a petition seeking sterilization); Schwartz, Fleischner, Schmidt, Gates, Costanzo, \& Winkelman, Protecting The Rights And Enhancing The Dignity Of People With Mental Disabilities: Standards For Effective Legal Advocacy, 14 RUTGERS L.J. 541, 570-72 (1983) (asserting that substituted judgment, not best interest, is the correct standard for representing the mentally disabled) [hereinafter Schwartz]. 
is the ultimate issue in the case and binding upon the court. ${ }^{133}$ In the context of representing an immature client, the substituted judgment determines only the position advocated by the child's attorney, whereas the court will consider other views and factors in making the final determination of the issues in the case.

The attorney should base a substituted judgment determination on a synthesis of what a general reasonable and inature child would want and on the particular characteristics and preferences of the individual child. ${ }^{134}$ The attorney inust determine "what choices a coinpetent person with the characteristics, tastes, preferences, history and prospects of the incompetent would make to maximize his interests or wants-both those he presently has and those he is likely to have in the future."135

The attorney should base her substitute judgment on three types of information: evidence of what the immature child desires now; opinions of informed individuals concerning what the child will desire; and evidence of what similarly situated mature people wish had been advocated. The attorney's first and inost important source of information should be the child-client himself. Even though the child is not capable of making a considered decision, he is the best source of information concerning the decision he would inake if he were competent. An immature child can give indications of his tastes, values, and einotional attachments, which can be critical factors in determining the position of the particular child. Furthermore, the child may articulate an express position on the direction of the case or may indicate subsidiary preferences that affect the attorney's determination of the child's position.

For instance, if a custody dispute involves a choice between otherwise equivalent and equally loved parents, one of whom offered a wealthy and cultured city lifestyle while the other offered a simple but wholesome hife on a farm, the child's love for ballet or for animals would be a relevant factor for the attorney to consider. The attorney should determine such preferences by interviewing the child if he is capable of intelligible conversation and by observing the child in the pertinent settings, such as in the coinpany and hoine of each custody claimant.

Only if the attorney is unable to elicit sufficient indications of the child's desires from the child himself, should she then interview individuals who are well-acquainted with the child. The best informed source will generally be the child's parents or guardians and siblings, but their

133. For example, since individuals generally have liberty to dispose of their own property, a court's substituted judgment of an incompetent's property disposition would be the ultimate resolution of the issue.

134. See Schwartz, supra note 132, at 572; Chambers, supra note 102, at 561.

135. Robertson, Organ Donations By Incompetents and the Substituted Judgment Doctrine, 76 Colum. L. Rev. 48, 65 (1976). 
opinions may be distorted by bias or self-interest. Others who have spent concentrated tinie with him, such as a teacher, babysitter, or counselor may be able to offer valuable and potentially more objective information to the attorney. Such information could include the child's reactions to separation from each parent or guardian, as well as his habit of asking for a particular person when he is hurt, afraid, or in trouble. Similarly, the child's extended family, friends, neighbors, and social workers may provide the attorney with critical information.

However, determining the child's preferences is only the first step in assessing the position he would take if he were competent to inake a reasoned decision. Indeed, if the child is very immature, only ininimal evidence of his particular opinions may be discernible. The attorney must then assess the foundation and strength of the child's preferences to determine the respective weight they are to be given.

The foundation of the immature child's opinion concerns the logic and reason forming the basis of the child's desire. For example, a desire to "live with daddy because he lets me eat ice creain every day," should be given less weight than a desire to "live with daddy because he always histens to me and answers my questions." This assessment will necessarily require a value judgment by the attorney. The appropriate standard to be applied should be the opinion of a reasonable, inature person looking back upon a childhood desire. In the above example, a reasonable person would consider the latter opinion as more valid and deserving of consideration than the former.

The strength of the child-client's desire is also a factor in determining the weight to be given to his opmion. For instance, one child may waiver when expressing a preference for a custodial parent, whereas another may express hatred for one parent. The child-client may modify his views upon maturity, but he is likely to retain a conviction that the attorney representing him should have presented his strongly held opinions. Thus, even though a child is not competent to make a decision for himself, his attorney may determine that the child is so coinmitted to a particular position that even if competent, he would still wish his iminature desire to be respected. On the other hand, the client, once mature, might dismiss his earlier desire as a childish impulse that should not have been given dispositive weight by his attorney. The central point of this analysis is to assess the value of the child's wishes as a serious statement of personal choice. If the attorney concludes that the immature client has a deeply felt opinion which is unlikely to be changed by the child's increasing maturity, then the child's counsel should advocate that position.

If the attorney determines that the immature child-client's desires are not dispositive evidence of the position that the child-client would 
take if he were mature, two types of outside evidence should be considered. First, the attorney should consider any predictive opinions of what the particular child will think once he is mature. For example, the teacher of a neglected child might argue that the child is so attached to his siblings that when he is mature he would have wanted his attorney to have advocated preservation of his family unit.

Next, the attorney should consider any available evaluations or opinions of inature mdividuals who were once in the child-chent's situation. For example, $\mathrm{n} 1$ an action to terminate parental rights in order to free a child in foster care for adoption, the child's attorney should consider the views of adults who have remained in long-term foster care or who were freed for permanent adoption. ${ }^{136}$ Such hindsight studies of similarly situated imdividuals would assist the attorney im forecasting the future desires of the child-chent.

It is important to emphasize that the attorney is not to base her decision on her own preconceptions or moral and philosophical behefs, but on an adequate investigation of the particular situation. For example, the attorney should not rely on her own behef that female infants belong with their mothers, or that foster care agencies always make the correct decision, but should formulate a position only after meeting the child, family, and, if useful, such individuals as the child's teacher, mimister, scout leader, or babysitter to determime such facts as the child's attachment to, and interaction with, competing custody claimants.

The effect of using substituted judgment to formulate the child-client's position can be illustrated by applying the approach to a case previously discussed. In OFFER, several of the named plaintiffs were teenagers and undoubtedly capable of directing their own attorney. The younger foster children, while not necessarily mature enough to direct their attorney, were deeply attached to their foster mother, whom they considered their "real" mother. ${ }^{137}$ If the children suffered fear and pain upon separation from their foster mother and psychiatric evidence indicated such separation might cause serious emotional damage, then, although an attorney might personally believe a child's "best interest" was to be with his birth parents, the substituted judgment of the childclient's position would be that the child would want to remain with his foster parent. Hence, the child's attorney would be ethically bound to advocate preservation of the child's relationship with his foster parent, even at the cost of his birth parents' rights. Of course, the judge would still be able to consider the rights of all of the various parties involved.

136. See e.g., Triseliotis, Identity And Security In Adoption And Long-Term Fostering, 15(2-3) EARLY CHILD Development \& CARE 149 (June 1984) (comparing the reactions and development of adults who remained in long-term foster care with that of adoptees).

137. Chambers \& WALD, supra note 57, at 113. 


\section{CONCLUSION}

In a majority of cases, an attorney for a minor will have a clear-cut role. This is true when a child's parent or guardian is a completely disinterested party, able to direct the attorney in such standard cases as contract or tort actions against third parties. The attorney's role is also clear when the attorney has particular competence to determine the child's interest, such as when a fundamental interest of the child is at stake ${ }^{138}$ or only clear financial issues are involved.

The difficulty arises when there is an actual or potential conflict regarding what is in the child's "best interest." If the child-chent is mature enough to express a considered opinion, and understand the consequences of his decision, then the decision is his and his alone. The attorney has a role in advising and counselling him, but any disagreement with the child's eventual conclusion should not inhibit zealous advocacy of that client's position. This position may require selfrestraint, but the attorney must remember that her proper role is to represent her client, leaving it to the court to judge what is best. If the child is immature, the attorney must advocate a position based on her assessment of what the chent would decide if not handicapped by immaturity. Under these circumstances, the attorney's task is inore difficult, but the essential role, that of speaking for the child, remains unchanged.

Robyn-Marie Lyon*

138. For example, when the child's liberty is threatened by delinquency proceedings or his life is threatened by denial of medical treatment.

* B.A. 1983, University of California, Los Angeles; third-year student, Boalt Hall School of Law, University of California, Berkeley. 